\title{
RETAIL FOOD GROUP CO-BRAND STRATEGY - A CASE STUDY ANALYSIS IN THE AUSTRALIAN FRANCHISING SECTOR
}

\author{
Owen Wright, Griffith University, Australia \\ Peter Clarke, Griffith University, Australia
}

\begin{abstract}
This paper describes a case study of the Retail Food Group (RFG) and its co-branding arrangements. Co-branding is becoming increasingly popular in franchised retailing as a means of stimulating growth in a mature sector. This case study provides an organisational perspective of co-branding extending existing literature away from product specific co-branding to a retail format. The study reveals that incentives for introducing other franchised retail brands into the Retail Food Group brand portfolio include search for a suitable retail brand; attracting new customers; and resilience from internal and external competition. This preliminary investigation provides a starting point for a broader research study into cobranded franchising arrangements.
\end{abstract}

\section{INTRODUCTION}

This paper proposes that the wide variety of franchising arrangements (for example, multiple concept, and multiple unit franchising) have occurred in response to the sector's need for continued growth outside the prototypical model of franchising. Theories of franchising are explored and are found to be inadequate in accounting for current trends in the Australian franchised retail sector. The inquiry then focuses on the developing phenomenon of retail co-branding and its occurrence in the Australian franchising sector. Retail co-branding, especially within business format franchising is a new direction for franchising in Australia and has attracted little attention in relevant literature. Historically attention has focussed on product or ingredient co-branding. To address this deficiency, a case study on the Retail Food Group's brand portfolio development profiles the reasons why franchised retail co-branding was introduced within that system.

\section{RETAIL BRANDING AND FRANCHISING}

Branding is described as a name, symbol, design or a combination of these, which assists in identifying the brand with a unique sustainable competitive advantage (Keller \& Lehmann, 2006; Kent, 2003). This brand definition was extended to the retail brand by including elements such as store image, store personality and identity (Kent, 2003). This moulding of a retail brand is achieved through store design, functionality, customer service levels, merchandising (through the mix of private and/or generic brands) and personnel qualities (Aliwadi \& Keller, 2004; Dawson, 2001; Fernie, 1992). The combination of these facets creates customer satisfaction via the store as brand (Martenson, 2007). The extension of the retail brand into franchising involves the replication of a brand format through the sale of the retail concept to franchisees. Rubin (1978, p. 224) states that, "a franchise agreement is a contract between two (legal) firms, the franchisor and the franchisee. The franchisor is a parent company that has developed some product or service for sale; the franchisee is a firm that is set up to market this product or service in a particular location. The franchisee pays a certain sum of money for the right to market this product." This early definition was modified later to include a prototypical model of franchising through a business format franchise (Kaufmann \& Dant, 1996). The business format represents the retail brand in a franchise context, hence business format franchising. Early authors in franchising reflected that the prototypical nature of franchising involved the ownership of each retail outlet by a 'mom and pop' who ensured that brand attributes important to the franchise were presented in the best possible way (Hoffman \& Preble, 1991; Hunt, 1977; Kaufmann \& Dant, 1996).

\section{A critique of franchising and the Australian regulatory regime}

Studies of franchising established theoretical explanations into why companies expand using franchising as a growth mechanism. Firstly, resource constraints theory argues that franchising is a source of external capital needed for expansion by the franchisor (Caves \& Murphy, 1976; Hunt, 1973; Oxenfeldt \& Kelly, 1969). Hence, franchisees provide much needed financial and human capital to achieve rapid network growth. Secondly, the agent theoretic perspective states that franchising evolved to overcome monitoring problems associated with rapid and diverse geographic expansion (Norton, 1988; Rubin, 1978). Franchisees exert a greater degree of control over the everyday functions of the business because of their ownership capacity. This allows the franchisor to focus on expansion of the system rather than day-to-day management tasks. These theories provide some insight into why companies looked at franchising, initially for growth 
purposes rather than expansion through company owned operations (Lafontaine \& Kaufmann, 1994; Norton, 1995). While companies sought this desired expansion, regulatory bodies began to influence and direct the conduct and growth of franchise businesses. Despite the extensive compliance now required by the Australian Franchising Code of Conduct (1998) (The Code), this intervention into the franchising relationship does not appear to have influenced franchisors away from franchising (Frazer \& Lim, 2002). In contrast, rather than find alternatives to franchising, franchisors have sought and developed new strategies within the sector as a means of continuing a franchised expansion process. It would seem that these innovations have been necessary to overcome a slowing of growth in franchising (Frazer, 2000). Franchisors are now more likely to face difficulties in attracting and recruiting suitable franchisees because of federal regulation (Frazer \& Weaven, 2002). The slowing of growth is a major signal that franchising in Australia has reached a level of maturity (Frazer, 2000). Stagnating retail growth, high levels of franchising per capita, and legal constraints are the principal contributors to sector maturity. This maturation is occurring within retail markets, where the majority of traditional business format franchising has existed (Justis \& Judd, 2002; True, Pelton, \& Strutton, 2003). Having fully adopted statute and codified restrictions for their operations, the franchising fraternity now prosper via different and more complex growth strategies rather than the prototypical single unit franchising model (Kaufmann \& Dant, 1996). Franchises sought to expand their systems by utilising these more complex brand strategies to survive in a heavily regulated sector. This path evolved as a response to the more mature status of the sector. However, these techniques seem to have been adopted in an experimental rather than systematic fashion (Wright, Frazer, \& Merrilees, 2007).

\section{Development of New Types of Franchising Arrangements}

The following common definitions in this field of research form a basis for an understanding of these new franchising taxonomies. Single unit ownership franchising is the stereotypical model of franchising where each franchise unit is discretely owned by an individual franchisee. In earlier literature, a focus on different management styles (entrepreneurial, confederation and carbon-copy) existing within franchise systems and the degree to which this impacted on particular methods of growth, was explored (Castrogiovanni \& Justis, 1998). Those observations suggested that the franchisor population was much more heterogeneous than traditional distinctions between the broader types of franchising; that of product and business-format franchising, and licensing in the broader context of distribution (Mintzberg, 1979). As the service sector expanded in 1990s, entrepreneurs created mobile franchising systems to allow franchisees to provide personalised home delivery of services to clients (Chow \& Frazer 2003). Mobile franchisees tend to be hands-on operators, thought to be a means of minimising agency costs, such as shirking and free-riding, in a geographically spread franchise system (Norton, 1988). Mobile franchising arrangements are more prominent in the service industry sector (Frazer \& McCosker, 1999) and they tend to adhere to the single-unit franchising model (commonly known as 'man-in-a-van' franchises). Both the fixed and mobile single-unit franchises attract people who want to 'buy themselves a job'. That is, they are suitable for previously employed people wishing to enter business for the first time and who see franchising as a means of gaining independence. Businesses such as kiosk-style food outlets, domestic cleaning and pet grooming franchises rely heavily on this traditional single unit franchising model because the franchisee is a hands-on owneroperator. Multiple unit franchising occurs where a franchisee owns more than one unit in a single franchise system (Frazer \& Weaven, 2002; Kaufmann \& Dant, 1996). The original model of franchising was the entrepreneur-franchisor enlisting 'mom and pop' franchisees who each held a single unit. However, expansion under this traditional method can be slow and ineffective, as large numbers of franchisees need to be recruited, selected and trained. A more efficient method of expansion is to offer suitable franchisees multiple units in the franchise network. Australia seems to be lagging behind the United States with regard to multiple-unit franchising. In the United States the majority of franchisees hold multiple units in their respective networks. In contrast, only 43 percent of Australian franchisors encourage multiple unit ownership (Frazer \& Weaven, 2002). Multiple unit franchising has been defined in terms of two broad approaches, direct and indirect multiple unit ownership. Differentiation occurs through the extent of influence from the franchisor. Master franchising and area representation agreements are indirect forms in which the franchisor rescinds responsibilities to the master franchisee. Alternatively, sequential and area development agreements are direct forms of multiple unit expansion in which franchisees are permitted to open, own and manage their own subsystem of franchised units (Weaven \& Frazer, 2003). Next, multiple concept franchising occurs when a franchisor adopts a number of concepts under a single trading name. An example is Jim's Group, which started as Jim's Mowing but then expanded the offering to include another 30 similar, but not competing, franchise concepts such as dog washing, car cleaning and fencing. This style of franchising differentiates itself from other diversified franchise operations by gaining its synergy from using franchising itself as a form of expansion rather than the retail offering. In Australia, it is difficult for most franchises to grow to the large size common in the United States because of our much smaller and limited population base. Hence, multiple concept franchising enables franchisors to achieve a larger size by offering similar franchises under a single brand name. The franchisor's resources can be spread 
more efficiently over the range of concepts, thus economising on administrative and franchise support costs (Wright \& Frazer, 2004). This distribution philosophy is encouraging franchise companies to offer multiple concepts to franchisees, so that the franchisees can sell goods and services to the same customer base repetitively, and cost effectively (Hayes, 1995). In Jim's Group the strategic focus is still very much on the home services market. The next level is multiple system franchising in which the franchisor diversifies into two or more unrelated franchise operations. The Retail Food Group in Australia operates Donut King and bb's cafe, Brumby's Bakeries and Michelle's Patisserie as separate entities. The franchisor commenced operating the four systems discretely in the market and has historically looked for synergies in the franchisor management and administrative functions. Examples of multiple system franchising are rare and current trends would appear to be away from this concept into the co-branded operating system where franchise and business synergies can be found. Retail Food Group has recently sought to combine these retail concepts into co-branded operations in the last two years. Another expansion option is via conversion franchising which occurs when an existing independently owned business or a competitor's franchisee is enlisted into the franchise network (Preble, 1995). It is a common method of rapid expansion in the marketplace by a franchisor. The benefit to the franchisor is the rapid acquisition of a network of franchisees, many of which are already operating successfully. Problems include the cost of conversion and retaining of a franchisee that is accustomed to operating independently. The franchisee benefits by becoming part of a large network, which has an established brand name and which will improve sales turnover. The downside may be the switch from independence to an interdependent relationship within the franchise network, and the need to pay franchise fees. The prevalence of conversion franchising has increased to a level where it is now a form of growth inherent in all markets rather than a particular managerial tool to assist system development. These retail franchising arrangements have been explained to provide a backdrop for a deeper discussion of co-branding in the retail franchise sector. Retail co-branded franchising occurs when two or more brands are combined, in various forms, to synergise a business, product or promotional offering at a single customer contact point (Wright, Frazer, \& Merrilees, 2007). Each brand discretely attracts current and new customers through such venture models as strategic alliance, joint venture, or partial or complete merger (Aaker \& Joachimsthaler, 2000; Blackett \& Boad, 1999; de Chernatony, 1998; Keller, 2003; Young, Hoggatt, \& Paswan, 2001). Traditionally this approach develops synergies through co-branding of specific products or ingredients in the area of fast moving consumer goods rather than the merging of entire organizations. However, the application of this concept appears to be appropriate across all venture models (Wright, Frazer, \& Merrilees, 2007). The types of franchises operating in a true synergistic co-branded format (two or more merged entities controlled by the same holding company or franchisor and operated by a single franchisee) are increasing. The best example of this style of co-branding is Allied Domecq's operation in the United States, as franchisor of the three systems of Dunkin Donuts, Baskin Robins and Togo's in one retail location (Zuber, 2001). Although this type of co-branding has occurred in the United States since the 1980s, it is a relatively new phenomenon in Australia. Variations of co-branding practices can be illustrated by Starbuck's arrangement to locate within selected Commonwealth Bank premises and similar arrangements by fast food outlets such as McDonald's alignment with BP service stations and Hungry Jacks with Shell. In its most refined form, co-branding embraces a collaborative venture constructed to further the interests of two, or more, organisations in a planned, strategic format (Aaker \& Joachimsthaler, 2000; Blackett \& Boad, 1999). While this view focuses on the organisational function of co-branding, there must be a customer focus at a specific location to differentiate co-branding from other forms of brand associations or synergies. Cobranding, therefore, must encompass a number of brands being joined to reach target audiences of similar interest (Temporal, 2002). However, companies may choose a brand portfolio strategy as an initial phase prior to co-branding. A brand portfolio is described as a group of brands, including sub-brands and co-brands (as well as other companies' brands that are used in a co-branded situation) that a company creates to offer to the market (Aaker \& Joachimsthaler, 2000). Retail Food Group, a publicly listed company since June 2005, has created a portfolio of retail brands to significantly boost its market presence (Aaker \& Joachimsthaler, 2000) and reinvigorate brand equity through co-branding, rather than deriving a positive brand association from the parent brand (Keller \& Lehmann, 2006). Each retail brand was either created or acquired to add franchise and retail synergy to the group. Retail Food Group's co-brand strategy attracts multiple market segments simultaneously to patronise a range of facilities provided by the combined retail entities in a single location. This combined customer focus through a co-brand integration moves away from other forms of brand associations such as a brand extension (Aaker \& Joachimsthaler, 2000; Keller, 2003). Retail Food Group's (RFG) group of retail brands is a collaborative intra-company venture constructed to further the interests of two or more independent brands in a planned, combined strategic format, and therefore, an ideal focus for this research. The data collection in this case preceded the arrangement with Michelle's and Brumby's, consequently the discussion relates solely to Donut King and bb's café.

\section{METHODOLOGY AND DATA COLLECTION}


Given the exploratory nature of the research, the contemporary nature of retail co-branding and its limited, but growing, appearance within the Australian retailing sector a case study method was deemed appropriate (Yin, 2003). Data were stored and analysed using qualitative software (QSR NVivo). Case study research was an appropriate design as this research focused on a contemporary set of events, investigating phenomena over which the researcher had no control. Therefore, this method allowed the investigation to explore the holistic and meaningful characteristics of real life events in an organisational setting. This study uses a single embedded design to provide the basis for a broader investigation using a multiple, holistic case study design. Therefore, Retail Food Group was chosen for theoretical, not statistical, reasons with the qualitative approach allowing the richness of the data to unfold through the collection and analytic process (Eisenhardt, 1989). Evidence for this case study was collected from multiple sources within the Retail Food Group. These included data provided from public documents such as the company prospectus, annual reports and finally an in-depth interview with the Group Director of Marketing. The selected data fairly represents the company and its activities. Next, the establishment of a chain of evidence ensured that explicit links between the questions asked, the data collected and the conclusions drawn were detailed, enabling crosschecking of evidence. Finally, the third tactic to address construct validity involved asking the informant to review all transcripts. An important factor in any research design is establishing methodological soundness (Eisenhardt, 1989). Qualitative research does not provide the level of external validity and reliability as quantitative research. However, strong measures were taken to build strength in this case study research at the research design, data collection and data analysis stages (Carson, Gilmore, Perry, \& Gronhaug, 2001). Three tactics were used in this research to address the issue of construct validity: the use of multiple sources of evidence; establishing a chain of evidence; and having the key informants review their interview transcripts. In addition, the tactics used to address internal validity were pattern matching and addressing rival explanations (Patton, 2002). Tactics used to address internal validity were pattern matching and addressing rival explanations. Pattern matching involved systematically matching patterns with literal replications and theoretical replications to ensure that the causal explanations were consistent. No rival explanations were found so there was no analysis necessary for negative or discrepant information that ran counter to the themes. External validity was not a concern in this pilot stage of the research, but the ultimate use of a multiple case strategy will address concerns about external validity via the application of replication logic using analytical generalisation across other case studies (Yin 2003). Case study tactics used to ensure reliability of results in this research were: the use of a case study protocol; use of a semistructured interview protocol; and the development of a case study database (Carson, Gilmore, Perry, \& Gronhaug, 2001). Data analysis is central to building theory from case studies, but also represents the most difficult and least codified part of the process (Eisenhardt, 1989). In the current pilot study, a within-case analysis took place (Yin, 2003) where data collection and data analysis occurred simultaneously. Ultimately, when multiple cases are considered, theoretical saturation or convergence will occur (Carson, Gilmore, Perry, \& Gronhaug, 2001; Eisenhardt, 1989).

\section{FINDINGS}

Three central themes emerged from the case study to illustrate and offer possible motivations for the development of cobranding in franchising. These themes are: search for a suitable retail brand: attracting new customers; and resilience from internal and external competition. This section outlines the supporting evidence of the themes' and their relevancy and impact. Search for a suitable retail brand - Significant emphasis was placed on the value a potential retail brand (i.e., a potential retail format and the subsequent offering) might provide to current Donut King or bb's cafe sites. The motivation for this was to extend the groups retail format by adding other external brands rather than extending the merchandise range. Interviewees stated that evaluation of potential brands involved the following criteria. This explanatory criteria used in conjunction with a grading process covered trading hours, product merchandise, fit with current operations, culture and systems, site location and size. An excerpt from the Retail Food Group's prospectus reinforces this position. "Potential direct cost savings may be achieved through improvements in compliance, reporting systems, and general administrative costs. Other potential benefits of scale include increased negotiating leverage with shopping centres on rental costs, suppliers of goods and services to the Company's franchise systems. The continuing development of the Donut King and bb's café menus to increase customer purchase frequency and average purchase value, encouragement of multi-outlet Franchisees and assessing and undertaking suitable acquisition." RFG's focus is on improving the current system as well as acquiring suitable retail brands. After this data were collected RFG acquired two brands. Those of Brumby's Bakery and Michelle's Patisserie, both of which will be integrated into the portfolio and subsequently co-branded opportunities will be sort. Attracting new customers - New customer segments were attracted to the co-brand of bb's cafe and Donut King by creating separate areas for the two brands. This involved creating specific interior and exterior design features, targeted advertising, and the general geographic location of the sites. This resulted in surges of patronage from current and new customers. As stated by the Group Director of Marketing, this was, “....more about getting recognition of the bb's brand. ...Once upon a time Donut King was more well known. There was an opportunity for us to split the kiosk and get some 
recognition of the (lesser known) brand." This strategy resulted in an increase in sales and profit. As stated in the Retail Food Group prospectus, there is a "... continuing development of the Donut King and bb's café menus to increase customer purchase frequency and average purchase value through encouragement of multi-outlet franchisees." (Retail Food Group, 2005). Subsequently this brand portfolio strategy reinvigorated the both brands. Grouping units in a co-brand improved their sales and profitability without requiring additional stand alone retail units to be added to the chain. Hence, rather than continue to invest heavily in new outlets RFG introduced a strategy of investing in current sites in order to improve system performance. Resilience from internal and external competition - From a corporate perspective, the combination of Donut King and bb's cafe is seen as a potential strategy to manage competitive threats to the system. Prior to the introduction of bb's cafe, Donut King sales and subsequent profitability were becoming increasingly difficult to maintain because competitors were affecting system market share. After the introduction of bb's cafe at specific sites the effect of competition has decreased. The Director of Marketing reinforced this by stating that, "Yes, look there was and I would say that it was a very short period of time and I would say it was because people are always inquisitive to try something new. Everybody will do that. So yes we did experience customer loss, but our customers came back." While the co-brand model was found to be more robust against external competition other RFG non co-branded outlets (Donut King and bb's cafe) lost sales when the new concept was introduced close by. This created a great deal of friction within the franchise system. Subsidisation schemes were also created to assist franchisees to create co-branded outlets so the roll-out could be fast tracked. This produced a faster expansion of the co-brand concept.

\section{DISCUSSION}

Franchisors have historically used simple retail concepts distributed by local operators at discrete locations. Agent-theoretic and resource constraints perspectives provided well accepted insights into the motivations for franchisors to undertake and develop this distribution strategy. As the retail brand has developed and become more complicated, both theories appear to weaken. Further, regulation of franchising has potentially forced a divergence away from the prototypical model of franchising through. Thus, franchised brand development has evolved into a number of different forms including retail cobranding. The themes developed in this case study highlight the complex and difficult process that co-branding creates in a franchised retail environment. It is clear that RFG spent significant resources in creating, finding and acquiring suitable brands for portfolio development in its franchised framework. Rather than co-brand with other external brands (with significant equity) RFG chose to either create or purchase its own brands to develop a portfolio. Once absorbed into the RFG system the retail brands were merged to form the co-brand of Donut King and bb's cafe. This attracted old and new customers thereby reinforcing the brand against competitor activity. This development is supported by traditional cobranding theory. However, franchisees of non co-branded sites were adversely affected by the co-brand concept. The new retail concept eroded the efforts of current franchisees (utilised in the original retail concept because of their ownership capabilities). While this anomaly was not originally foreseen by RFG executives, they nevertheless capitalised on the situation to ensure the co-brand strategy was adopted as quickly as possible by all franchisees. While agency theory supported the franchise activities pre-co-brand the introduction of the new concept created many difficulties in the franchising relationship. Further, subsidisation was used to initiate this further development of the co-brand concept. If franchisees are originally attracted to invest their capital in the franchise concept then why subsidise the same franchisees to update the retail concept in a contemporary environment. Clearly, RFG sees that the long-term development of the cobrand concept will contribute higher levels of profitability than corporate controlled retail outlets.

\section{FUTURE RESEARCH}

Retail Food Group's development of co-branding arrangements appears successful. Further research into this group and the combined four brands is warranted because strategy variations may emerge. Other research possibilities include access to limited shopping centre space, strip grouping of like retail outlets from a franchise viewpoint or consumer reactions of delight or confusion.

\section{CONCLUSION}

In summary, several themes emerged from the data that provide explanations for co-branding in franchising. RFG commenced with a brand portfolio and then adopted a strategy of co-branding to provide synergy to support firstly, the development of the relatively weak bb's cafe brand and secondly, to reinvigorate the Donut King brand. While the brand portfolio strategy was develop initially, co-branding, although a complicated and difficult strategy to implement, appears to have been a more successful strategy than a company owned retail outlets into discrete locations. 


\section{REFERENCES}

Aaker, D., \& Joachimsthaler, E. (2000). Brand Leadership. New York: The Free Press.

Aliwadi, K., \& Keller, K. (2004). Understanding retail branding: conceptual insights and research priorities. Journal of Retailing, 80, 331-342.

Blackett, T., \& Boad, B. (1999). Co-Branding: The Science of Alliance. London: Macmillan Business.

Carson, D., Gilmore, A., Perry, C., \& Gronhaug, K. (2001). Qualitative Marketing Research. London: SAGE Publications.

Castrogiovanni, G., \& Justis, R. (1998). Franchising Configurations and Transitions. Journal of Consumer Marketing, 15(2), 170-190.

Caves, P., \& Murphy, W. (1976). Franchising: Firms, Markets and Intangible Assets. Southern Economic Journal, 42(April), 572-586.

Dawson, J. (2001). Is there a new commerce in Europe. International Review of Retail, Distribution and Consumer Research, 11(3), 287-299.

de Chernatony, L. (Ed.). (1998). Brand Management. Aldershot: Dartmouth Publishing Company.

Eisenhardt, K. (1989). Building Theories from Case Study Research. Academy of Management Review, 14(4), 532-550.

Fernie, J. (1992). Distribution Strategies of European Retailers. European Journal of Marketing, 26(8-9), 35-47.

Frazer, L. (2000). Assessing franchising sector maturity: Australian evidence. Australasian Marketing Journal, 8(2), 33-46.

Frazer, L., \& Lim, J. (2002). Introducing Franchising Regulation: An Analysis of the Australian Franchising Code of Conduct. Journal of Marketing Channels, 10(2), pp. 39-56.

Frazer, L., \& McCosker, C. (1999). Franchising Australia 1999 : a survey of franchising practices and performance.

Toowoomba: University of Southern Queensland.

Frazer, L., \& Weaven, S. (2002). Franchising Australia 2002 Survey. Brisbane: Griffith University.

Hayes, J. (1995, March-April). Multi-Concept Franchising Sharpens Competitive Edge. Franchising World, 27, 54-61.

Hoffman, R., \& Preble, J. (1991). Franchising: Selecting a Strategy for Rapid Growth. Long Range Planning, 24, 74-85.

Hunt, S. (1973). The Trend Toward Company-Operated Units in Franchise Chains. Journal of Retailing, 49(Summer), 312.

Hunt, S. (1977). Franchising: Promises, Problems, Prospects. Journal of Retailing, 53(3), 71-83.

Justis, R., \& Judd, R. (2002). Franchising (2nd ed.). Cincinnati: Dame-Thomson Learning.

Kaufmann, P., \& Dant, R. (1996). Multi-Unit Franchising: Growth \& Management Issues. Journal of Business Venturing, 11(5), 343-358.

Keller, K. (2003). Strategic Brand Management : Building, Measuring, and Managing Brand Equity (2nd ed.). Upper Saddle River, N.J.: Prentice Hall.

Keller, K., \& Lehmann, D. (2006). Brands and Branding: Research Findings and Future Priorities. Marketing Science, 25(6), 740-759.

Kent, T. (2003). 2D23D: Management and design perspectives on retail branding. International Journal of Retail and Distribution Management, 31(3), 131-142.

Lafontaine, F., \& Kaufmann, P. (1994). The Evolution of Ownership Patterns in Franchise Systems. Journal of Retailing, 70(2), 97-113.

Martenson, R. (2007). Corporate brand image, satisfaction and store loyalty: A study of the store as a brand, store brands and manufacturer brands. International Journal of Retail and Distribution Management, 35(7), 544-555.

Mintzberg, H. (1979). Structuring of Organizations. Englewood Cliffs, NJ: Prentice Hall.

Norton, S. (1988). An Empirical Look at Franchising as an Organisational Form. Journal of Business, 61(2), 197-218.

Norton, S. (1995). Is franchising a capital structure issue? Journal of Corporate Finance, 2(1-2), 75-101.

Oxenfeldt, A., \& Kelly, A. (1969). Will Successful Franchise Chains Ultimately Become Wholly-Owned Chains? Journal of Retailing, 44, 66-87.

Patton, M. (2002). Qualitative Research and Evaluation Methods (3rd ed.). Thousand Oaks: Sage Publications.

Preble, J. (1995). Franchising Systems Around the Globe: A Status Report. Journal of Small Business Management, 33(2), 80-89.

Retail Food Group. (2005). Retail Food Group Prospectus. Brisbane: Retail Food Group.

Rubin, P. (1978). The Theory of the Firm and the Structure of the Franchise Contract. Journal of Law and Economics, 21, 223-233.

Temporal, P. (2002). Advanced Brand Management: From Vision to Valuation. Singapore: John Wiley \& Sons.

True, S. L., Pelton, L. E., \& Strutton, D. (2003). The lost frontier in entrepreneurship: Aggregation, saturation and decimation of the franchising channel. Journal of Marketing Channels, 11(1), 79-89. 
Weaven, S., \& Frazer, L. (2003). Predicting Multiple Unit Franchising: A Franchisor and Franchisee Perspective. Journal of Marketing Channels, 10(3/4), pp. 53-82.

Wright, O., \& Frazer, L. (2004). The future of franchising in a mature sector: An Australian perspective. Paper presented at the International Society of Franchising, Las Vegas.

Wright, O., Frazer, L., \& Merrilees, B. (2007). McCafe: The McDonald's Co-branding Experience. Journal of Brand Management, 14(6), 442-458.

Yin, R. (2003). Case Study Research: Design and Methods (3rd ed.). Thousand Oaks: Sage Publications.

Young, J., Hoggatt, C., \& Paswan, A. (2001). Food service franchisors and their co-branding methods. Journal of Product \& Brand Management, 10(4), 218-227.

Zuber, A. (2001, 5/02/2003). To market, to market: Chains find strength in numbers, use co-branding as growth vehicle. Nation's Restaurant News, 35, 45-48. 